ROCZNIKI TEOLOGICZNE

Tom LXVIII, zeszyt 2 - 2021

DOI: https://doi.org/10.18290/rt21682-7

ANTON ADAM

\title{
THEOLOGICAL ICONS OF THE VIRGIN MARY IN THE TEACHINGS OF POPE FRANCIS
}

\begin{abstract}
A bstract. At the center of the world's attention is man as a being who is called to complete his life in communion with God. To fulfill this purpose, after the fall of the first people, God sends his Son, who received human nature from his mother - the Virgin Mary. The motherhood of Jesus ${ }^{\circ}$ mother is the reason for taking the right attitude toward the woman through whom we received the Creator of life. It is rightly spoken of the Marian veneration, which is shown by the cult of hyperdulia. The doctrine of the Catholic Church takes a position on all the important aspects of this reverence as well as the correct attitude of the believer to mariological topics that resonate in theological circles. An important and irreplaceable role is also played by the teachings of the popes, which are presented in different ways and on different occasions. Pope Francis takes a stand on the issues arising from the participation of the Virgin Mary in the history of salvation. In the study we will point out the theological images of the Virgin Mary in the teachings of Pope Francis as they are contained in the documents of his pontificate.
\end{abstract}

Keywords: Church; Mary; icon of faith; mother; Christ.

The central event in the history of salvation is the incarnation of the Son of God-Jesus Christ. In general, the way in which a man of sin is called to the fullness of a new life is emphasized. The very work of redemption culminates in Christ's death on the wood of the cross and his glorious resurrection. After going to Heavenly Father, he leaves us alone, but entrusts the care of our souls to the Church, of which it remains a cornerstone and also establishes the head of this visible community. The apostle St. Peter is the first to take responsibility, listening clearly to the words of Christ's commission: "And I tell

Prof. ThDr. AnTON ADAM, PhD-Comenius University in Bratislava, Faculty of Roman Catholic Theology of Cyril and Methodius, Kňazský seminár sv. Gorazda v Nitre; address for correspondence: Banská 28, 97632 Badín, Slovakia; e-mail: tonciadam@gmail.com 
you that you are Peter, and on this rock I will build my church, and the gates of Hadeswill not overcome it. I will give you the keys of the kingdom of heaven; whatever you bind on earth will bebound in heaven, and whatever you loose on earth will beloosed in heaven" (Mt 16:18-19).

And subsequently, in the history of the Church, there are other popes who accept and take responsibility for the pastors for the community entrusted to them. Each of them in the historical context is subjected to a certain analysis, to which both anthropological aspects and verbal formulations are aimed at expressing attitudes to current issues of their time. It is clear that some personalities of the papacy remain written deep in the historical memory, and it often happens that the people give them a certain adjective to point out the specific character of either the personality itself or the way the Church is led. If St. John Paul II. He is often referred to as the "Marian" pope, to refer to his deep and filial attitude and relationship with his heavenly mother, Mary. We realize that the very relationship with the Virgin Mary stems from the reality of her divine motherhood. She humbly accepted the invitation to an exceptional motherhood and became open to receiving God's will. Theological doctrine and faithful teaching on the standstill and presence of the Virgin Mary in the history of salvation play an important role in shaping not only religious knowledge but also the subsequent relationship of the believer to the Mother of God, which is demonstrated by the cult of hyperdulia. The priest of Christ receiving the sacramental priesthood by the very nature of the service received is open to Marian veneration. During his pontificate, pope Francis demonstrates an equally close relationship with the mother of our Lord, Mary. We can present it both on the anthropological-pastoral and ecclesial level. The present study aims to introduce theological icons in the teachings of Pope Francis.

From the first moments of his pontificate, Pope Francis is constantly entrusted with the protection of the Virgin Mary. The next day after the election, he went with a bouquet of flowers to the Pauline Chapel of the Basilica of Santa Maria Maggiore, where he prayed in front of the miraculous image of the Mother of God Salus populi romani and then went to the altar above the mangers in this basilica, where St. Ignatius of Loyola celebrated your first holy mass. We can rightly think that in those moments, far from his native Argentina, he remembered Our Lady of Luján, the patron saint of Argentina, but perhaps also the Virgin Mary of Guadalup, who is deeply revered by all of Latin America. Interestingly, in the life of Pope Francis we often find events associated with the date of the 13th day of the 
month, which commemorates the day of the apparition of Fatima. Jorge Mario Bergoglio received the ordination of the priesthood on November 13, 1969. Information about his appointment as bishop came on 13th of May in 1992, and on 13th of March in 2013, he was elected bishop of Rome - the successor of the Apostle St. Peter.

\section{MARY, MOTHER OF EVANGELIZATION}

In his apostolic exhortation to the Gospel, Pope Francis calls Gaudium Mary, „the Mother of Evangelization.” She points to Mary's steadfastness in the history of salvation as the Mother of our Redeemer standing in the midst of the people. "She gathered disciples to summon him (cf. Acts 1:14), thus enabling the missionary explosion that took place in Pentecost. She is the Mother of the Evangelizing Church, and without her we cannot fully comprehend the spirit of the new evangelization."1 Let your light so shine before men, that they may see your good works, and glorify your Father which is in heaven" (Mt 5:16). The Mother of God is a type of man of deep and personal faith that leads her to fulfill God's mission. To her-as our spiritual mother-our attention is drawn so that in her humble thinking and actions we may find our own way of spiritual conversion and live in friendship with God. The invitation to a life of love and grace also resonates in the many words of the Virgin Mary, which were also heard in Marian revelations. The man of faith is to witness the presence of the Church in the world today, just as the Virgin Mary is present in the life of each one of usas the mother of our Lord.

Pope Francis placed Mary in the center of the Church. In a post-synodal apostolic exhortation to the young and all of God's people, Christus vivit says: "Mary shines in the heart of the Church. He is a great example for the young Church who wants to follow Christ with freshness and suppleness. When she was young, she accepted the angel's proclamation and was not afraid to ask questions (cf. Lk 1:34) But she had a willing soul and said, "I am the Lord's servant" (Lk 1:38). ${ }^{2}$

The gospel as the good news of our redemption is an integral part of every human life. It is worth noting that not only the life of a believer. God

\footnotetext{
${ }^{1}$ Francis, Apostolic Exhortation Evangelii gaudium, 284.

${ }^{2}$ Francis, Post-Synodal Apostolic Exhortation Christus vivit, 43.
} 
comes to all people, and Christ's sacrifice on the cross is a sacrifice for all people. Just as the redemptive work of Jesus Christ has a universal character, so the Gospel follows this framework. The Second Vatican Council speaks of a universal plan of salvation, which has its origin in the goodness of Heavenly Father, who loves all people: ,and he did not forsake them, even when they fell in Adam, but always gave them the means of salvation with regard to Christ the Redeemer, who "is the image of the invisible God, the firstborn of all creation" (Col 1:15). ${ }^{3}$ The Council Fathers devoted space to a wide range of salvation issues. They present ideas of the Church's relationship to non-Christians, who may also participate in salvation: "But God is not far from others who seek the unknown God in shadows and images, [...] he hemself gives everyone life, breath, and everything else" (Acts 17:25-28) and as the Savior wants to save all people (cf. $1 \mathrm{Tm} \mathrm{2:4).}$ For those who, through no fault of their own, do not know the gospel of Christ and his Church, but seek God with a sincere heart and, under the influence of grace, strive to do his will, known by the voice of conscience, can attain eternal salvation." ${ }^{4}$ Pope saint John Paul II. recalls the ecclesial context of the universal saving will of God, with an emphasis on a certain place of the Virgin Mary in the whole context of this truth. In the encyclical Redemptoris Mater, he says: „Mary is present in the Church as the Mother of Christ, and at the same time as that Mother whom Christ, in the mystery of the Redemption, gave to humanity in the person of the Apostle John. Thus, in her new motherhood in the Spirit, Mary embraces each and every one in the Church, and embraces each and every one through the Church." ${ }^{5}$ Pope Francis says in this context: "There is a Marian "style" to the Church's work of evangelization. Whenever we look to Mary, we come to believe once again in the revolutionary nature of love and tenderness. In her we see that humility and tenderness are not virtues of the weak but of the strong who need not treat others poorly in order to feel important themselves." ${ }^{6}$ The dogmatic constitution Lumen gentium points to Mary's virtues to be followed by the Church: „But while in the most holy Virgin the Church has already reached that perfection whereby she is without spot or wrinkle (cf. Eph 5:27), the followers of Christ still strive to increase in holiness by conquering sin. [...] For Mary, who since her entry into salvation history unites in herself

\footnotetext{
${ }^{3}$ Second Vatican Council, Dogmatic Constitution Lumen gentium, 2.

${ }^{4}$ Lumen gentium, 16.

${ }^{5}$ John Paul II, Encyclical Redemptoris Mater, 47.

${ }^{6}$ Evangelii gaudium, 288.
} 
and re-echoes the greatest teachings of the faith as she is proclaimed and venerated, calls the faithful to her Son and His sacrifice and to the love of the Father." " Mary is close to us, because she went through many life trials, in which her faith was fully manifested, a constant readiness to be devoted to God. Mary also lives the Gospel in Joseph's disappointment, which she could not explain to him, in the forced emigration, when Herod reached for her child, in the loss of the twelve-year-old Jesus in Jerusalem, in the persecution of Jesus from the Pharisees and enemies, but also at the height of Christ's life his suffering, crucifixion and death. In a post-synodal apostolic exhortation, Pope Francis writes:

Without yielding to evasions or illusions, she accompanied the suffering of her Son; she supported him by her gaze and protected him with her heart. She shared his suffering, yet was not overwhelmed by it. She was the woman of strength who uttered her "yes," who supports and accompanies, protects and embraces. She is the great guardian of hope... From her, we learn how to say "yes" to the stubborn endurance and creativity of those who, undaunted, are ever ready to start over again. ${ }^{8}$

The decision of Pope Francis, who in 2018 established a compulsory liturgical memory of the Virgin Mary, Mother of the Church, is closely related to the icon of Mary as the Mother of Evangelization. The Church is the means of evangelization, and Mary has her irreplaceable place in this work. On the day of the celebration of the memory of Mary, mother of the Church, the Congregation for Divine Worship and Discipline of the Sacraments established a decree published on March 3, 2018, signed by Prefect Robert Sarah on February 11, 2018, on the feast of Our Lady of Lourdes. The Prefect of the Congregation for Divine Worship and the Discipline of the Sacraments, Cardinal Robert Sarah, justified the choice of the liturgical celebration of Our Lady of the Church in these words: „Considering the importance of the mystery of Mary's spiritual motherhood has not ceased to care for the church traveling in time. Pope institutes new celebration of Mary, Mother of Church. Pope Francis inserts the Memorial of the Blessed Virgin Mary, Mother of the Church, into the Roman Calendar on the Monday following Pentecost Sunday. ${ }^{9}$ Within the ecclesial framework, Pope Francis places the presence of the Virgin Mary in prayer in anticipation of

\footnotetext{
${ }^{7}$ Lumen gentium, 65.

${ }^{8}$ Christus vivit, 45.

${ }^{9}$ See on the link: https://www.vaticannews.va/en/pope/news/2018-03/pope-institutes-newcelebration-of-mary--mother-of-church.html. Accessed October 30, 2020.
} 
the Holy Spirit, which is already a consequence of her constant participation in events connected with the son of Jesus Christ: "When her young son needed protection, Mary set out with Joseph to a distant land (cf. Mt 2:1314). She also joined the disciples in awaiting the outpouring of the Holy Spirit (cf. Acts 1:14). In her presence, a young Church was born, as the apostles went forth to give birth to a new world (cf. Acts 2:4-11)."

\section{MARY, THE PERFECT ICON OF FAITH}

The New Testament texts are reminiscent of Jesus' words, in which he formulates the essence of faith in him with the faith of God the Father: "Whoever believes in me does not believe in me only, but in the one who sent me. The one who looks at me is seeing the one who sent me. I have come into the world as a light, so that no one who believes in me should stay in darkness." (Jn 12:44-46). To receive Jesus presupposes being a person of personal commitment to God to such an extent that he shows him boundless trust. On this path, however, there is a constant need for strengthening of faith in order to succeed in all circumstances of life. Jesus Christ exhorts Peter to do this task as he prays for him: „Simon, Simon, Satan has asked to sift all of you as wheat. But I have prayed for you, Simon, that your faith may not fail. And when you have turned back, strengthen your brothers" (Lk 22:31-32). Peter of these times too - Pope Francis strengthens the faith of the members of the Church; he directs his encouragement to other people on various occasions. He associates the attitude of faith with good soil. In other words, when a person listens carefully to God's voice, he keeps this word in his heart and acts according to it. In such a case, it is not the listener who hears the word and acts according to his opinion, but it is the attitude of a man sincerely open to the word of God, by which he addresses him and subsequently acts in this spirit. In his encyclical Lumen fidei, Pope Francis focuses on Luke's Gospel, which also mentions the parable of the sower; Pope Francis applies this parable to the Virgin Mary: "In the context of Luke's Gospel, this mention of an honest and good heart which hears and keeps the word is an implicit portrayal of the faith of the Virgin Mary. The evangelist himself speaks of Mary's memory, how she treasured in her heart all that she had heard and seen, so that the word could bear fruit (Lk 8:15) in

\footnotetext{
${ }^{10}$ Christus vivit, 47.
} 
her life. The Mother of the Lord is the perfect icon of faith; as Saint Elizabeth would say: "Blessed is she who believed" (Lk 1:15). ${ }^{11}$ In the context of Luke's Gospel, the mention of a good and noble heart in relation to listening to and keeping God's word is an implicit sketch of the faith of the Virgin Mary. The same evangelist tells us about Mary's memory, about how she kept in her heart everything she heard and saw so that the Word could bear fruit in her life. The Mother of the Lord is, as St. Elizabeth says, a perfect icon of faith: "Blessed is she who believes" (Lk 1:45). Mary believed and lived her faith with Jesus. Mary gave birth to Christ by faith ${ }^{12}$ and "led by the Holy Spirit received the Word of life in the depths of her humble faith." 13 Pope Francis says in an encylcical devoted to the care of common home: "She not only "kept" (cf. Lk 2:19, 51) all the whole life of Jesus, but now she also understands the meaning of all things. That is why we can ask her to help us look at this world with wiser eyes." 14 We consider the Virgin Mary to be our mother in faith, because in the diversity of her life she remained a woman of faith just as her ancestor Abraham (cf. Rom 4:3; 18-19). Mary is closely connected with what we believe in. Mary is described as a "pilgrim in faith," 15 but also as a "woman of faith." 16 In the encyclical Lumen fidei, she presents the Christocentric dimension of the history of salvation in the anthropological framework of human history: „The movement of love between Father and Son in the Holy Spirit has passed through our history; Jesus draws us to himself so that he can save us (cf. Jn 12:32). At the heart of the faith is the confession that Jesus, the Son of God, born of a woman, leads us into adoptive sonship through the gift of the Holy Spirit (cf. Gal 4: 4-6)."17

At the end of the first encyclical Lumen fidei addressed to bishops, priests and deacons, consecrated persons and laity believers, in which he focuses on faith, we find deep words of prayer in which Pope Francis addresses Mary,

\footnotetext{
${ }^{11}$ Francis, Encyclical Lumen fidei, 58.

${ }^{12} \mathrm{Cf}$. Evangelii gaudium, 285.

${ }^{13}$ Evangelii gaudium, 288.

${ }^{14}$ Francis, Encyclical Laudato si', 241. Cf. Marian Šuráb, “Ako rozprávat' počas liturgie o mariánskych zjaveniach,” in Anton Adam, Mária - Matka v každej dobe (Badín: APRINT s.r.o., 2017), 386.

${ }^{15}$ Lumen fidei, 58.

${ }^{16}$ Evangelii gaudium, 287. Referring to Mary's faith, Pope Francis follows the teachings of John Paul II, especially his encyclical Redemptoris Mater. Cf. Jana Moricová, "Panna Mária ako vzor teologálnych čností podl’a učenia pápeža Františka," in Teologálne čnosti z interdisciplinárneho pohl'adu, ed. Miloš Lichner SJ (Trnava: Dobrá kniha, 2018), 289-291.

${ }^{17}$ Lumen fidei, 59.
} 
the Mother of the Church and the Mother of our faith. May these words be the request of our Christian being as well:

Mother, help our faith! Open our ears to hear God's word and to recognize his voice and call. Awaken in us a desire to follow in his footsteps, to go forth from our own land and to receive his promise. Help us to be touched by his love, that we may touch him in faith. Help us to entrust ourselves fully to him and to believe in his love, especially at times of trial, beneath the shadow of the cross, when our faith is called to mature. Sow in our faith the joy of the Risen One. Remind us that those who believe are never alone. Teach us to see all things with the eyes of Jesus, that he may be light for our path. And may this light of faith always increase in us, until the dawn of that undying day which is Christ himself, your Son, our Lord! ${ }^{18}$

The figure of Mary leads us to reflect on the mission entrusted to her by God and at the same time addresses obedience to the message that the angel brings. Mary responds in obedience with the words "Behold, the handmaid of the Lord; let it be to me according to your word" (Lk 1:38), which may be an inspiration to man of the present time to renounce his intentions and direct attention to the fulfillment of God's will. Pope Francis says: "By her 'fiat,' Mary became the mother of God's Son, not losing but, thanks to him, consecrating her virginity. In her, we see the Mother of God who does not keep her Son only to herself, but invites everyone to obey his word and to put it into practice" (cf. Jn 2:5). ${ }^{19}$

\section{MARY IN THE CARE OF JOSEPH}

The figure of Mary is most often introduced in connection with motherhood, when she accepts a special mission and becomes the mother of the Son of God. However, this picture needs to be supplemented by the figure of St. Joseph, who has an irreplaceable place in the Nazarene family. Although this figure of New Testament history is spoken of modestly, it nevertheless plays an important role that the New Testament Gospels speak of in connection with the birth of Jesus, but also the escape of the Nazarene family to Egypt. These are important moments for Pope Francis, which he points out when talking about the role and mission of the Virgin Mary. The evangelist St. Matthew speaks of St. Joseph not only at the birth of Jesus

\footnotetext{
${ }^{18}$ Lumen fidei, 60.

${ }^{19}$ Francis, Apostolic Letter Admirabile signum, 7.
} 
Christ (cf. Mt 1:18-25), but also mentions the event when the Nazarene family fled before Herod to Egypt (cf. Mt 2:13-22). St. Luke represents the birth of Jesus Christ in historical context, when a census was held for Emperor Augustus, and specifically speaks of Joseph: "And Joseph also went up from the town of Nazareth in Galilee, to Judea, to the city of David, which is called Bethlehem, because he was of the house and family line of David, to be registered along with Mary, who was engaged to him and was pregnant" (Lk 2:4-5). The quiet and inconspicuous Joseph is where his presence is needed to be available to his wife and mother of the Incarnate Word at the same time.

Pope Francis highlights the attitude of St. Joseph

At her side in the Holy Family of Nazareth, stands the figure of Saint Joseph. Through his work and generous presence, he cared for and defended Mary and Jesus, delivering them from the violence of the unjust by bringing them to Egypt. The Gospel presents Joseph as a just man, hard-working and strong. But he also shows great tenderness, which is not a mark of the weak but of those who are genuinely strong, fully aware of reality and ready to love and serve in humility. That is why he was proclaimed custodian of the universal Church. He too can teach us how to show care; he can inspire us to work with generosity and tenderness in protecting this world which God has entrusted to us. ${ }^{20}$

In the Apostolic letter Admirabile signum, Pope Francis speaks of the significance and importance of the nativity scene in Bethlehem; represents St. Joseph as the protector of the Child and his Mother. St. Joseph:

He is the guardian who tirelessly protects his family. When God warned him of Herod's threat, he did not hesitate to set out and flee to Egypt (cf. Mt 2:13-15). And once the danger had passed, he brought the family back to Nazareth, where he was to be the first teacher of Jesus as a boy and then as a young man. Joseph treasured in his heart the great mystery surrounding Jesus and Mary his spouse; as a just man, he entrusted himself always to God's will, and put it into practice. ${ }^{21}$

Pope Francis draws the attention not only of the Christian people but also of the world community to people who are leaving their countries and becoming refugees. It is a sign of Christian love to accept another person when he needs help by providing means that he cannot work on himself. In such situations, acceptance is important. In the Message for World Migrants and Refugees Day 2016, the Holy Father recalls the testimony of the Gospel:

\footnotetext{
${ }^{20}$ Laudato si', 242.

${ }^{21}$ Admirabile signum, 7.
} 
"At the heart of the Gospel of mercy the encounter and acceptance by others are intertwined with the encounter and acceptance of God himself. Welcoming others means welcoming God in person! Do not let yourselves be robbed of the hope and joy of life born of your experience of God's mercy, as manifested in the people you meet on your journey!" ${ }^{22}$ On this occasion, he reiterates the testimony of Mary and the care of Joseph, who had a personal experience of migration: "I entrust you to the Virgin Mary, Mother of migrants and refugees, and to Saint Joseph, who experienced the bitterness of emigration to Egypt. To their intercession I also commend those who invest so much energy, time and resources to the pastoral and social care of migrants. ${ }^{23}$

\section{MARY, THE CARING MOTHER OF THE SON, THE QUEEN OF ALL CREATION}

Pope Francis presents the mother of Jesus as the one who took care not only of her child, but also shows attention to the children of this world. In the encyclical Laudato si', we read: "Mary, the Mother who cared for Jesus, now cares with maternal affection and pain for this wounded world. Just as her pierced heart mourned the death of Jesus, so now she grieves for the sufferings of the crucified poor and for the creatures of this world laid waste by human power." ${ }^{4}$ The post-synodal apostolic exhortation addressing the young and the whole people of God thinks of Mary as a girl from Nazareth. The Pope writes of this girl: "Today, Mary is the Mother who watches over us, her children, on our journey through life, often weary and in need, anxious that the light of hope not fail. For that is our desire: that the light of hope never fail. Mary our Mother looks to this pilgrim people: a youthful people whom she loves, and who seek her in the silence of their hearts amid all the noise, the chatter and the distractions of the journey. Under the gaze of our Mother, there is room only for the silence of hope. Thus Mary illumines anew our youth." 25

\footnotetext{
${ }^{22}$ Francis, Message of His Holiness Pope Francis for the World Day of Migrants and Refugees 2016, Vatican, September 12, 2015. Available on the link: http://www.vatican.va/content/francesco/en/ messages/migration/documents/papa-francesco_20150912_world-migrants-day-2016.html. Accessed October 30, 2020.

${ }^{23}$ Ibidem.

${ }^{24}$ Laudato si', 241.

${ }^{25}$ Christus vivit, 48 .
} 


\section{MARY, MOTHER OF MERCY}

On various occasions, Pope Francis encourages acts of mercy, the fruit of which bears the redemptive work of Jesus Christ. In the Christological context, we find the interpretation of Mar's mission in her motherly medium, when she intercedes for us, because she is the Mother of merciful love. During the Apostolic Journey to Fatima on 12nd of May in, 2017, Pope Francis offered a prayer in the Chapel of Revelation, which also included the words of prayer:

Hail, Mother of Mercy, Lady robed in white! In this place where, a hundred years ago you made known to all the purposes of God's mercy, I gaze at your robe of light and, as a bishop robed in white, I call to mind all those who, robed in the splendour of their baptism, desire to live in God and tell the mysteries of Christ in order to obtain peace. [...] Hail, Mother of the Lord, Virgin Mary, Queen of the Rosary of Fatima! Blessed among all women, you are the image of the Church robed in paschal light, you are the honour of our people, you are the victory over every assault of evil. Prophecy of the merciful love of the Father, Teacher of the Message of Good News of the Son, Sign of the burning Fire of the Holy Spirit, teach us, in this valley of joys and sorrows, the eternal truths that the Father reveals to the little ones. ${ }^{26}$

Pope Francis often recalls the mercy of God, which we need to approach with constant confidence. In the bull, Misericordiae vultus emphasizes: "We need constantly to contemplate the mystery of mercy. It is a wellspring of joy, serenity, and peace. Our salvation depends on it. Mercy: the word reveals the very mystery of the Most Holy Trinity. Mercy: the ultimate and supreme act by which God comes to meet us. Mercy: the fundamental law that dwells in the heart of every person who looks sincerely into the eyes of his brothers and sisters on the path of life. Mercy: the bridge that connects God and man, opening our hearts to the hope of being loved forever despite our sinfulness." 27 It is clear from this statement that for a man of faith, mercy is to be the basic motive of Christian thought and action. The proclamation of the special Year of Mercy is associated by Pope Francis with the fiftieth anniversary of the end of the Second Vatican Council. Therefore, the

\footnotetext{
${ }^{26}$ Francis, Prayer of His Holiness Pope Francis to the shrine of our Lady of Fatima. Available on the link: http://www.vatican.va/content/francesco/en/prayers/documents/papa-francesco_preghiere_ 20170512 fatima.html. Accessed October 30, 2020.

${ }^{27}$ Misericordiae vultus, 2.
} 
beginning of the Holy Year of Mercy ${ }^{28}$ is announced on the feast of the Immaculate Conception of the Blessed Virgin Mary, on December 8, 2015. The documentary focuses on the Mother of Mercy, and Pope Francis formulates his attitude toward Mary, the Mother of Mercy, in the words:

My thoughts now turn to the Mother of Mercy. May the sweetness of her countenance watch over us in this Holy Year, so that all of us may rediscover the joy of God's tenderness. No one has penetrated the profound mystery of the incarnation like Mary. Her entire life was patterned after the presence of mercy made flesh. The Mother of the Crucified and Risen One has entered the sanctuary of divine mercy because she participated intimately in the mystery of His love. [...] Her hymn of praise, sung at the threshold of the home of Elizabeth, was dedicated to the mercy of God which extends from 'generation to generation' (Lk 1:50). We too were included in those prophetic words of the Virgin Mary. This will be a source of comfort and strength to us as we cross the threshold of the Holy Year to experience the fruits of divine mercy. ${ }^{29}$

Other pastoral activities of Pope Francis are also associated with Mary, Mother of Mercy. On the occasion of the extraordinary Holy Year of Mercy, the Church enabled believers to receive indulgences. In the Letter Pope Francis granting indulgences on the occasion of the extraordinary Holy Year of Mercy addressed to Mons. Rino Fisichell, President of the Pontifical Council in Support of the New Evangelization, we conclude: "Trusting in the intercession of the Mother of Mercy, I entrust the preparations for this Extraordinary Jubilee Year to her protection." ${ }^{30}$

The pastoral care of Pope Francis was also reflected in the Apostolic Letter Misericordia et misera [Mercy and Peace], which he presented on the day of the end of the extraordinary Holy Year of Mercy, November 20, 2016. Pope Francis states: "The Jubilee now ends and the Holy Door is closed. But the door of mercy of our heart continues to remain wide open." ${ }^{31}$ The Pope speaks of the great gifts of God's love, which we were able to contain and receive expressions of the love of a merciful God during the extraordinary Holy Year of Mercy. He represents Mary to believers with a wish for our

${ }^{28}$ The extraordinary Holy Year of Mercy began on the Feast of the Immaculate Conception of the Blessed Virgin Mary on December 8, 2015 and ended with the liturgical celebration of Christ the King on November 20, 2016.

${ }^{29}$ Misericordiae vultus, 24.

${ }^{30}$ Francis, Letter of His Holiness Pope Francis according to which an indulgence is granted to the fatithful on the occasion of the extraordinary Jubilee of Mercy. Available on the link: http:// www.vatican.va/content/francesco/en/letters/2015/documents/papa-francesco_20150901_letteraindulgenza-giubileo-misericordia.html. Accessed November 7, 2020.

${ }^{31}$ Francis, Apostolic Letter Misericordia et misera, 16. 
next life: "The Holy Mother of God always looks upon us with her eyes of mercy. She is the first to show us the way and to accompany us in our witness of love. As she is often shown in works of art, the Mother of Mercy gathers us all under the protection of her mantle. Let us trust in her maternal assistance and follow her perennial counsel to look to Jesus, the radiant face of God's mercy." 32 When we trust in Mary's motherly help, we fix our spiritual gaze on her faithfulness to God's voice, which makes her a model for Christians. In the Message for the 22nd World Day of the Sick in 2014, Pope Francis encourages with the words: "Mary, impelled by God's mercy which took flesh within her, selflessly hastened from Galilee to Judea to find and help her kinswoman Elizabeth. She interceded with her Son at the wedding feast of Cana when she saw that there was a shortage of wine." 33

In the context of merciful love, Pope Francis speaks of Mary, who, by her faith, unties the knot of sin. It refers to the words of St. Irenaeus, stated in the Constitution of the Second Vatican Council, Lumen gentium: "For, as St. Irenaeus says, she 'being obedient, became the cause of salvation for herself and for the whole human race." "34 Hence not a few of the early Fathers gladly assert in their preaching, "The knot of Eve's disobedience was untied by Mary's obedience; what the virgin Eve bound through her unbelief, the Virgin Mary loosened by her faith." 35 Comparing Mary with Eve, they call her "the Mother of the living," 36 and still more often they say: "death through Eve, life through Mary (cf. Jn 17:4)."

Referring to the title of the Virgin Mary, Mother of Mercy, we would like to mention the decision of Pope Francis to add three new invocations to the Virgin Mary in the Loreto litany. It will be addressed as "Mother of Mercy," "Mother of Hope" and "Consolation of Migrants." It is known that the Polish version of the Loreto Litany included the invocation "Mother of Mercy" in 2014, when, at the request of the Polish Episcopate, the Congregation agreed to this request.

\footnotetext{
${ }^{32}$ Misericordia et misera, 22.

${ }^{33}$ Francis, Message of Pope Francis for the 22nd World Day of the Sick 2014, article 4, Vatican, December 6, 2013. Available on the link: http:/www.vatican.va/content/francesco/en/messages/ sick/documents/papa-francesco_20131206_giornata-malato.html. Accessed November, 2020.

${ }^{34}$ Saint Irenaeus, Adv. haer. III, 22, 4: PG 7, 959A: Harvey, 2, 123.

${ }^{35}$ Saint Irenaeus, Adv. haer. III, 22, 4: PG 7, 959A: Harvey, 2, 124.

${ }^{36}$ Saint Epiphanius, Haer, 78, 18: PG 42 , 728CD - 729A.

${ }^{37}$ Saint Hieronymus, Epist. 22, 21: PL 1108. Cf. Saint Augustinus, Serm. 51, 2, 3: PL 38, 335; Serm. 232, 2: col. 1108; Saint Cyril of Jerusalem, Catech. 12, 15: PG 33, 741 AB; Saint John Golden Mouth, In Ps. 44, 7: PG 55, 193; Saint John of Adamascus, Hom. 2 in dorm. B. M. V., 3: PG 96, 728. Cf. Second Vatican Council, Dogmatic Constitution Lumen gentium, 56.
} 
The Prefect of the Congregation for Divine Worship and Discipline of the Holy Cardinal Robert Sarah writes in a letter from the Presidents of the Episcopal Conferences dated June 20 to the liturgical remembrance of the Immaculate Heart of Mary:

The Church, traveling toward heavenly Holy Jerusalem to enjoy an inseparable connection with Christ, her bridegroom and savior, walks the paths of history entrusting to the One who believed the Lord's word. We know from the Gospel that Jesus' disciples learned from the dawn to praise the "blessed among women" and to reckon with her maternal intercession. Christians have been using innumerable invocations and titles to call upon the Virgin Mary, as the privileged and sure way to an encounter with Christ. Referring to the present times, marked by feelings of uncertainty and trepidation. The People of God are sevoutly recourse to her, full of affection and trust.

Pope Francis, whishes to provide that in the formulary of the litany of the Blessed Virgin Mary called 'The Litany of Loreto', the ivocations 'Mater misericordiæ', 'Mater spei' and 'Solacium migrantium' should be inserted. According to directions, the invocation, 'Mother of mercy' is to be inserted after 'Mother of the Church', 'Mother of hope' after 'Mother of Divine Grace' and 'Solace of migrants' after 'Refuge of sinners ${ }^{38}$

\section{MARY - THE FIRST DISCIPLE OF THE LORD}

In the statements of Pope Francis, the image of the Virgin Mary is associated with her participation in the life of Jesus Christ. She is silent and at the same time inconspicuously present in events that affect not only in relation to the son, but in the work of the mediator, the whole of humanity. She is a mother standing under a cross, from which she does not leave, but in her mother's pain she stands as a witness to victory over the evil of sin. If Christ became the teacher of all, Mary is his first disciple. In the Letter to the People of God, Pope Francis draws attention to Mary's attitude as she stood under the cross. "Mary chose to stand at the foot of her Son's cross. She did so unhesitatingly, standing firmly by Jesus' side. In this way, she reveals the way she lived her entire life. [...] She, the first of the disciples, teaches all of us as disciples how we are to halt before the sufferings of the

\footnotetext{
${ }^{38}$ Pope adds three new invocations to the Litany of the Blessed Virgin Mary. Available on: https://www.vaticannews.va/en/pope/news/2020-06/pope-francis-loreto-litany-new-invocations.html. Accessed November 7, 2020.
} 
innocent, without excuses or cowardice. To look to Mary is to discover the model of a true follower of Christ." ${ }^{39}$

Consecrated life has a constant and important place in the history of the Church. It is not only men and women religious, but also lay people who, in various forms of consecrated life, develop the universal charism of love. Pope Francis has a personal experience of consecrated life not only as a priest of Christ, but also as the spiritual son of St. Ignatius of Loyola. Certainly this is one of the reasons why the Pope pays due attention to consecrated life. Mother Mary dedicated her entire earthly life to the service of the Son, whom she conceived by the Holy Spirit and gave birth to. Pope Francis also points to Mary in an apostolic letter addressed Apostolic letter to all consecrated people on the occasion of the year of consecrated life, which began on the Feast of the Sacrifice of the Virgin Mary on November 21, 2014. All consecrated God finds the words of spiritual encouragement: "I entrust this Year of Consecrated Life to Mary, the Virgin of listening and contemplation, the first disciple of her beloved Son. Let us look to her, the highly-beloved daughter of the Father, endowed with every gift of grace, as the unsurpassed model for all those who follow Christ in love of God and service to their neighbour." 40 Mary is ready to act responsibly to fulfill God's purpose. Being a disciple presupposes an open approach to the teacher with a desire to contain the truth he proclaims and to which we are called. Mary is a type of true disciple because she is willing to act in this way. Pope Francis in the Message to the Pontifical Mission Societies, May 21, 2020, gives an example of Mary's attitude: „I already mentioned to you in one of our encounters, imitate the ready spirit of Mary. When she visited Elizabeth, Mary did not do so on her own: she went as a servant of the Lord Jesus, whom she carried in her womb. She said nothing about herself, but simply brought her Son and praised God. It was not about her. She went as the servant of the One who is the sole protagonist of missionary activity." ${ }^{41}$ Mary is the mother

\footnotetext{
${ }^{39}$ Francis, Letter of His Holiness Pope Francis to the People of God, Vatican, August 20, 2018. Available on the link: http://www.vatican.va/content/francesco/en/letters/2018/documents/papafrancesco_20180820_lettera-popolo-didio.html. Accessed November 8, 2020.

${ }^{40}$ Francis, Apostolic Letter of His Holiness Pope Francis to all Consecrated People on the Occasion of the Year of Consecrated Life, Vatican, November 21, 2014. Available on the link: http://www.vatican.va/content/francesco/en/apost_letters/documents/papa-francesco_lettera-ap_ 20141121_lettera-consacrati.html. Accessed November 8, 2020.

${ }^{41}$ Francis, Message of His Holiness Pope Francis to the Pontifical Mission Societies. Conclusion. Available on the link: http://www.vatican.va/content/francesco/en/messages/pont-messages/2020/ documents/papa-francesco_20200521_messaggio-pom.html. Accessed November 8, 2020.
} 
with whom we see that to love the Lord means to love people, and vice versa. "When we look at Mary, he helps us and constantly teaches us to turn his face to the Lord." ${ }^{42}$ Her words in Cana of Galilee are a constant reference to your Son: "Whatsoever he saith unto you, do it" (Jn 2:5).

The Mother of God is a woman of deep and personal faith, in whom he always finds a way of fulfilling God's mission. Our attention is turned to Mary, so that in the witness of her humble thoughts and actions we may find our own way of constant communion with God. Mary is present in our lives because she is the Mother at all times. It is necessary to point to the new image of the Mother of Jesus in the context of dynamism, which in the New Testament history of salvation, in its ever-present "fiat" follows the path of faithful fulfillment of God's will. ${ }^{43}$ Reflecting on the prayer Hail Mary, Pope Francis expressed a relationship with the Virgin Mary: „What do I think when I look at the Mother of God? It is certainly beautiful to look at Madonna, but it is even more beautiful to allow her to look at us and to tell her everything in the knowledge that she is looking at us." ${ }^{44}$ This idea fully corresponds with the images of the Virgin Mary as perceived and formulated by Pope Francis in his statements on various occasions in the performance of the pastoral office as Peter's successor. In conclusion, it is worth noting that Pope Francis also uses other images of the Virgin Mary, which are not often mentioned, but appear in his statements. They are: Mother of the Prince of Peace; The mother of all nations on earth; Our Lady, Madonna della Strada; Maria, Salus informorum; Mother of Christ the Savior; Mother of hope; Mary, a loving Mother; Mary, Mother of Evangelization; Our Lady, a noble icon of redeemed humanity, the missionary pattern of the Church; Mary, Mother of Migrants and Refugees; Mary, Mother of Consolation; Mary, the Seat of Wisdom; Mary, Mother of the Poor; Mary, Star of the New Evangelization; Mary, Mother of All the Sick; Mary, the way to God.

\footnotetext{
${ }^{42}$ Pope Francis and Marco Pozza, Zdravas Mária (Trnava: Spolok sv. Vojtecha, 2018), 9.

${ }^{43}$ Cf. Anton Adam, "Mariánsky kult - 30 rokov exhortácie Marialis cultus," Duchovný pastier. Revue pre teológiu a duchovnýživot 85, no. 5 (2004): 289.

${ }^{44}$ Pope Francis and Pozza, Zdravas Mária, 49.
} 


\section{BIBLIOGRAPHY}

Adam, Anton. "Mariánsky kult - 30 rokov exhortácie Marialis cultus.” Duchovný pastier. Revue pre teológiu a duchovný život 85, no. 5 (2004): 287-90.

Francis. Apostolic Exhortation Evangelii gaudium. Accessed November 7, 2020. http://www.vatican.va/ content/francesco/en/apost_exhortations/documents/papa-francesco_esortazione-ap_20131124_ evangelii-gaudium.html.

Francis. Apostolic Letter Admirabile signum. Accessed November 5, 2020. http://www.vatican.va/ content/francesco/en/apost_letters/documents/papa-francesco-lettera-ap_20191201_admirabilesignum.html.

Francis. Apostolic Letter Misericordia et misera. Accessed November 5, 2020. http://www.vatican.va/ content/francesco/en/apost_letters/documents/papa-francesco-lettera-ap_20161120_misericordia-etmisera.html.

Francis. Apostolic Letter of His Holiness Pope Francis to all Consecrated People on the Occasion of the Year of Consecrated Life. Vatican, November 21, 2014. Accessed November 7, 2020. http:// www.vatican.va/content/francesco/en/apost_letters/documents/papa-francesco_lettera-ap_20141121 _lettera-consacrati.html.

Francis. Bull Misericordiae vultus. Accessed October 20, 2020. http://www.vatican.va/content/ francesco/en/apost_letters/documents/papa-francesco_bolla_20150411_misericordiae-vultus.html.

Francis. Encyclical Laudato si'. Trnava: Spolok Svätého Vojtecha, 2015. http://www.vatican.va/ content/francesco/en/encyclicals/documents/papa-francesco_20150524_enciclica-laudato-si.html.

Francis. Encyclical Lumen fidei. Trnava: Spolok Svätého Vojtecha, 2015. http://www.vatican.va/ content/francesco/en/encyclicals/documents/papa-francesco_20130629_enciclica-lumen-fidei.html.

Francis. Letter of His Holiness Pope Francis to the People of God. Vatican, August 20, 2018. Accessed November 11, 2020. http:/www.vatican.va/content/francesco/en/letters/2018/documents/papafrancesco_20180820_lettera-popolo-didio.html.

Francis. Letter of His Holiness Pope Francis According to Which an Indulgence is Granted to the Fatithful on the Occasion of the Extraordinary Jubilee of Mercy. Accessed November 7, 2020. $\mathrm{http} / /$ www.vatican.va/content/francesco/en/letters/2015/documents/papa-francesco_20150901_ lettera-indulgenza-giubileo-misericordia.html.

Francis. Message of Pope Francis for the 22nd World Day of the Sick 2014. Vatican, December 6, 2013. Accessed November 11, 2020. http://www.vatican.va/content/francesco/en/messages/sick/ documents/papa-francesco_20131206_giornata-malato.html.

Francis. Message of his Holiness Pope Francis for the World Day of Migrants and Refugees 2016. Vatican January 17, 2016. Accessed October 30, 2020. http://www.vatican.va/content/francesco/ en/messages/migration/documents/papa-francesco_20150912_world-migrants-day-2016.html.

Francis. Message of His Holiness Pope Francis to the Pontifical Mission Societies. Rome, May, 21. Accessed November 8, 2020. http://www.vatican.va/content/francesco/en/messages/pont-messages/ 2020/documents/papa-francesco_20200521_messaggio-pom.html.

Francis. Post-Synodal Apostolic Exhortation Christus vivit. Accessed November 7, 2020. http:// www.vatican.va/content/francesco/en/apost_exhortations/documents/papa-francesco_esortazioneap_20190325_christus-vivit.html.

Francis. Prayer of His Holiness Pope Francis to the Shrine of our Lady of Fatima. Accessed October 30, 2020. http://www.vatican.va/content/francesco/en/prayers/documents/papa-francesco_preghiere_ 20170512_fatima.html. 
John Paul II. Encyclical Redemptoris Mater. Trnava: Spolok Svätého Vojtecha, 1999. http:// www.vatican.va/content/john-paul-ii/en/encyclicals/documents/hf_jp-ii_enc_25031987_redemptorismater.html.

Moricová, Jana. "Panna Mária ako vzor teologálnych čností podl’a učenia pápeža Františka." In Teologálne čnosti z interdisciplinárneho pohl'adu Zborník príspevkov z interdisciplinárnej medzinárodnej vedeckej konferencie, edited by Miloš Lichner SJ, 285-300. Trnava: Dobrá kniha, 2018.

Pope Francis and Marco Pozza. Zdravas Mária. Trnava: Spolok Svätého Vojtecha, 2018.

Second Vatican Council. "Dogmatic constitution Lumen gentium." In Dokumenty Druhého vatikánskeho koncilu. Trnava: Spolok sv. Vojtecha, 2008. https://www.vatican.va/archive/ hist_councils/ii_vatican_council/documents/vat-ii_const_19641121_lumen-gentium_en.html

Vatican News. https://www.vaticannews.va/en/pope/news/2020-06/pope-francis-loreto-litany-newinvocations.html

\title{
TEOLOGICZNE IKONY MARYI W NAUCZANIU PAPIEŻA FRANCISZKA
}

\author{
Streszczenie
}

Z opracowanego tematu teologicznej ikony/teologicznych ikon (podl’a Tvojho uváženia) Matki Bożej w nauczaniu papieża Franciszka wynika, że relacja współczesnego następcy św. Piotra do Bogurodzicy jest bardzo żywa i wielowymiarowa, czego dowodem jest jego zajmowanie stanowiska w różnych kwestiach mariologicznych oraz częste przedstawianie Maryi, Matki naszego Pana, jako wzoru do naśladowania dla wiernych znajdujących się w rozmaitych sytuacjach życiowych. Na podstawie niniejszego przedłożenia można stwierdzić, że papież naświetla relację do Matki Bożej przede wszystkim z punktu widzenia duszpasterskiego oraz że podejmowane przez niego prawdy wiary pozostają na płaszczyźnie stwierdzeń. Ojciec Święty najczęściej zajmuje się tematem wiary Maryi, przedstawiając ją równocześnie jako Matkę ewangelizacji. Poświęca uwagę także wzajemnej relacji Maryi i św. Józefa, podkreślając jego nieustanną gotowość do troskliwej opieki nad Świętą Rodziną. Papież Franciszek często zachęca wiernych do przyjmowania daru Bożego miłosierdzia oraz mówi o Maryi jako o Matce Miłosierdzia, przy czym tak czyni w kontekście chrystologicznym. Jest oczywiste, że papieskie przedstawianie Maryi jako pierwszej uczennicy Pana wywodzi się z jej bliskiej relacji do Jezusa. Mariologia papieża Franciszka nie została skumulowana do jednego konkretnego dokumentu, ale jego myśli mariologiczne znajdują się niby drogocenne perły rozproszone w rozmaitych dokumentach jego nauczania.

Słowa kluczowe: Kościół; Maryja Dziewica; ikona wiary; matka; Chrystus. 